\title{
Parasitic dinoflagellate Hematodinium perezi prevalence in larval and juvenile blue crabs Callinectes sapidus from coastal bays of Virginia
}

\author{
H. J. Small ${ }^{1, *}$, J. P. Huchin-Mian ${ }^{1,3}$, K. S. Reece ${ }^{1}$, K. M. Pagenkopp Lohan ${ }^{1,4}$, \\ M. J. Butler IV ${ }^{2}$ J. D. Shields ${ }^{1}$ \\ ${ }^{1}$ Virginia Institute of Marine Science, William \& Mary, PO Box 1346, Gloucester Point, VA 23062, USA \\ ${ }^{2}$ Department of Biological Sciences, Old Dominion University, Norfolk, VA 23529, USA \\ ${ }^{3}$ Present address: Department of Biology, Division of Natural and Exact Sciences, University of Guanajuato, Noria Alta s/n, \\ Guanajuato 36050, Mexico \\ ${ }^{4}$ Present address: Marine Disease Ecology Laboratory, Smithsonian Environmental Research Center, Edgewater, MD 21037, USA
}

\begin{abstract}
The parasitic dinoflagellate Hematodinium perezi infects the American blue crab Callinectes sapidus and other decapods along the Eastern seaboard and Gulf of Mexico coast of the USA. Large juvenile and adult blue crabs experience high mortality during seasonal outbreaks of $H$. perezi, but less is known about its presence in the early life history stages of this host. We determined the prevalence of $H$. perezi in megalopae and early benthic juvenile crabs from multiple locations along the Virginia portion of the Delmarva Peninsula. The DNA of $H$. perezi was not detected in any megalopae collected from several locations within the oceanic coastal bay complex in which $H$. perezi is found at high prevalence levels. However, prevalence levels were high in early benthic juveniles from 2 oceanic coastal embayments: South Bay and Cobb Bay. Prevalence levels were lower at locations within Chesapeake Bay, including Cherrystone Creek, Hungars Creek, and Pungoteague Creek. Sampling over different seasons and several consecutive years indicates that disease transmission occurs rapidly after megalopae settle in high-salinity bays along the Delmarva Peninsula during the late summer and fall. Infected juvenile crabs can overwinter with the parasite and, when subjected to increasing water temperatures in spring, infections progress rapidly, culminating in transmission to other crabs in late spring and early summer. In high-salinity embayments, $H$. perezi can reach high prevalence levels and may significantly affect recruitment of juvenile blue crabs into the adult fishery.
\end{abstract}

KEY WORDS: Dinoflagellate $\cdot$ Parasite $\cdot$ Crustacea $\cdot$ Endemic $\cdot$ Infection

\section{INTRODUCTION}

The blue crab Callinectes sapidus is an abundant, highly mobile, benthic predator with a complex life history. The species is distributed from Nova Scotia (Canada) to Brazil (Williams 1984) and supports economically important fisheries along the Eastern seaboard and Gulf of Mexico coast of the USA. In the last decade, however, there have been major declines in harvest yields of many blue crab fisheries in the

${ }^{*}$ Corresponding author: hamish@vims.edu
USA. Fishing pressure and habitat loss contribute greatly to those declines, but disease and environmental processes affecting blue crab populations have not been thoroughly researched, although both have contributed to declines and changes in population cycles in other crustacean fisheries (Shields 2012). In particular, few studies have examined the effects of pathogens upon settlement of postlarvae or new recruits, yet pathogens are often most prevalent in and damaging to the early juvenile stages of crustaceans. 
The blue crab serves as a host for a variety of pathogens, including viruses, bacteria, fungi, protozoa, helminths, and other crustaceans (Shields \& Overstreet 2007). Most pathogens cause little pathological alteration to the host, but several have the capacity to cause serious disease and significantly affect host populations and their associated fisheries. For instance, the parasitic dinoflagellate Hematodinium perezi causes widespread blue crab mortalities during annual seasonal outbreaks (Messick 1994, Messick \& Shields 2000, Lee \& Frischer 2004). The parasite was first documented in blue crabs by Newman \& Johnson (1975) and was later shown to have a broad distribution on the Eastern seaboard of the USA and Gulf of Mexico coast (Messick \& Shields 2000, Pagenkopp Lohan et al. 2013). The parasite is endemic in crabs living in areas of high salinity (>20 psu), and infections are rarely found in waters where salinity is below 18 psu (Newman \& Johnson 1975, Messick \& Sindermann 1992, Messick \& Shields 2000). The parasite also infects several other crustacean species, including decapods and amphipods (Johnson 1986, Messick \& Shields 2000, Sheppard et al. 2003, Pagenkopp Lohan et al. 2012).

$H$. perezi can be highly pathogenic in its blue crab host, with mortality rates up to $87 \%$ in naturally and experimentally infected mature blue crabs (Messick \& Shields 2000, Shields \& Squyars 2000). Infections and crab mortalities have historically been reported from large juvenile and adult crabs due to their ease of capture in commercial traps; few studies have examined larval and early benthic juvenile stages. Messick (1994) documented prevalence levels up to $100 \%$ in early benthic juveniles sampled in 1992 and 1993 from coastal bays near Ocean City, Maryland, and Franklin City, Virginia. Little is known about whether the parasite can infect larval stages. Sullivan et al. (2016) and Sullivan \& Neigel (2017) detected Hematodinium DNA associated with blue crab megalopae collected from inshore locations in Louisiana, but their studies did not demonstrate whether the positive PCR assays were associated with internal infections.

The purpose of the current study was to determine if megalopae had infections of $H$. perezi and to assess the prevalence levels in early benthic juveniles from both intermediate- and high-salinity locations along the Virginia portion of the Delmarva Peninsula. Diagnostic PCR was employed to screen initial collections of juvenile crabs and megalopae. Subsequent crab collections were screened by tissue smears that allowed us to semi-quantitatively assign an intensity of infection and document the life stages of the parasite.

\section{MATERIALS AND METHODS}

\subsection{Collection and treatment of experimental animals}

In 2008 and 2009, juvenile blue crabs were obtained from colleagues studying the relationship between submerged aquatic vegetation (SAV) cover and juvenile crab density (Ralph et al. 2013). Crabs were collected from Cherrystone Creek and Hungars Creek, 2 moderate-salinity (18-22 psu) locations on the Chesapeake Bay side of the Delmarva Peninsula (Fig. 1), by suction sampling, transported to the Virginia Institute of Marine Science (VIMS), and frozen at $-20^{\circ} \mathrm{C}$. Samples were then thawed and sorted, and individual crabs were measured (carapace width [CW] including epibranchial spines) prior to their preservation in $70 \%$ ethanol. In 2011 and 2012, early benthic juvenile crabs were collected from SAV habitats in Cherrystone Creek and South Bay, a highsalinity (32-34 psu) oceanic coastal embayment on the Delmarva Peninsula. Crabs were captured using dip nets and immediately stored in coolers containing ambient seawater for transport to VIMS for assessment. Upon return to the laboratory, crabs were preserved whole in 95\% ethanol. All subsequent collections from SAV habitats (2014-2017) were conducted in the same manner. Over this period, crabs were also collected from Cobb Bay, which abuts South Bay. In fall 2016, juvenile crabs were also collected from Pungoteague Creek and Gwynn's Island, 2 moderate-salinity locations (16$18 \mathrm{psu}$ ) on the Chesapeake Bay side of the Delmarva Peninsula and on the western shore of Chesapeake Bay, respectively. At the laboratory, crabs were measured and assessed for obvious injuries prior to dissection. They were then bisected sagittally along the carapace length using a sterile razor blade on a clean glass microslide. Half of the crab was placed into Bouin's solution and the other half was placed into $95 \%$ ethanol for later processing. The dissection smear was then stained with $0.3 \%$ neutral red in physiological saline and assessed for the presence of the parasite.

Megalopae were collected from several high-salinity (28-34 psu) locations on the Eastern Shore of Virginia (Fig. 1) during late summer and fall 2010 using larval collectors. The collectors were made of 'horsehair' filter material wrapped around and tied to a $1 \mathrm{~m}$ section of $15 \mathrm{~cm}$ PVC pipe weighted on one end by concrete and buoyed on the other by half a standard crab float. These were deployed in shallow waters tethered by rope to anchors. The collectors were de- 


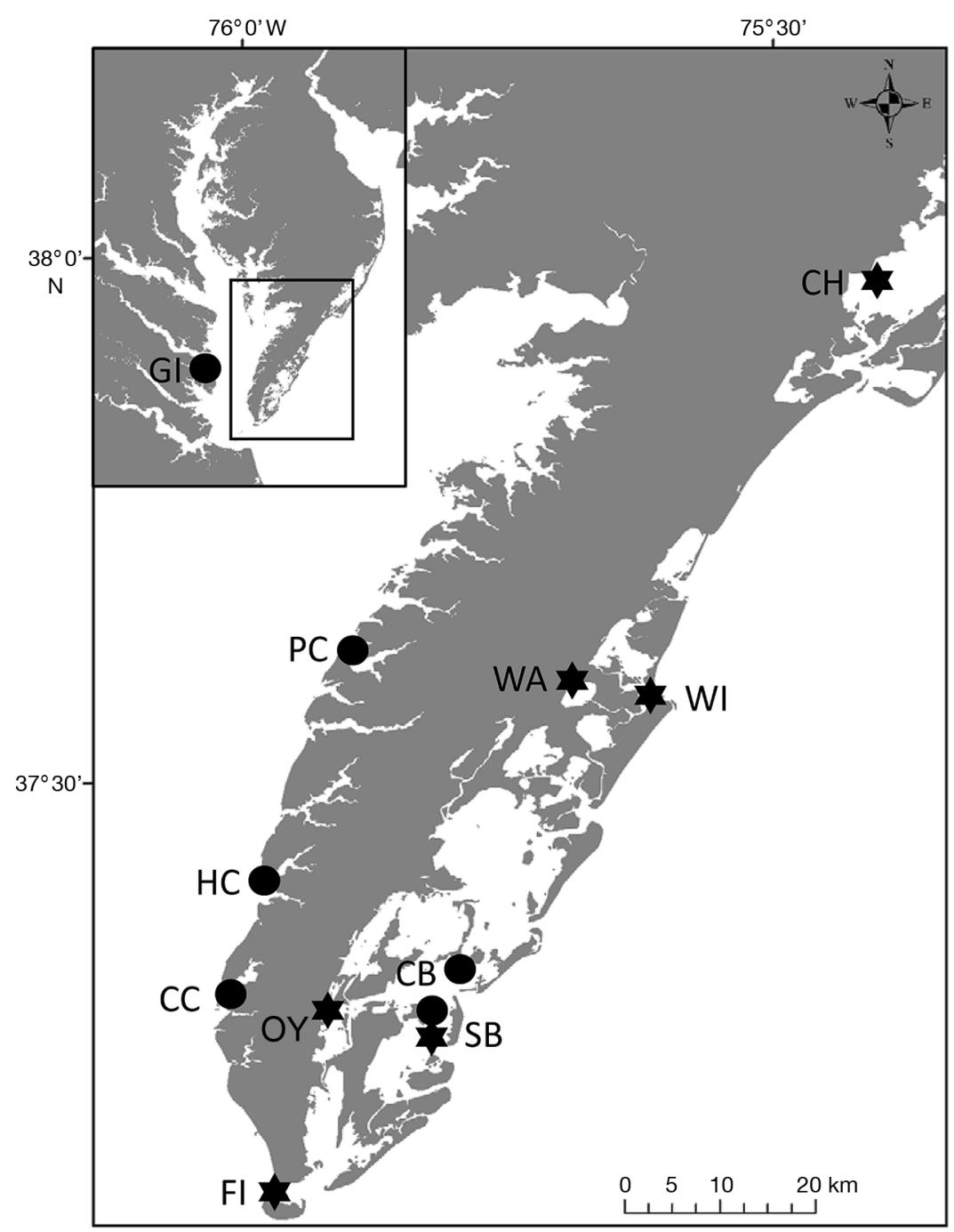

Fig. 1. Eastern Shore of Virginia, USA, showing sample locations. Inset shows Chesapeake Bay. Stars indicate megalopae collections, circles indicate juvenile crab collections. CB: Cobb Bay; CC: Cherrystone Creek; $\mathrm{CH}$ : Chincoteague Bay; FI: Fisherman's Island; GI: Gwynn's Island; HC: Hungers Creek; OY: Oyster Harbor; PC: Pungoteague Creek; SB: South Bay; WA: Wachapreague Creek; WI: Wachapreague Inlet

ployed overnight around the period of the full or new moons. Collectors were recovered the morning of the following day and the filter material washed onto a $200 \mu \mathrm{m}$ sieve. Washed megalopae were carefully recovered from the sieve and preserved in 95\% ethanol for later processing.

\subsection{Nucleic acid extraction and diagnostic PCR}

Ethanol-preserved megalopae (see Section 2.1) and juvenile blue crabs from 2008, 2009, 2011, and 2012 were assessed by PCR for the presence of
Hematodinium perezi. DNA was extracted from individual megalopae and juveniles. Based on their CW, juvenile crabs were subjected to DNA extraction either as a whole crab $(<5 \mathrm{~mm} \mathrm{CW})$, half of a crab (5-10 mm CW), or gill tissues that were dissected from larger crabs (>10 mm CW). Prior to extraction, megalopae and crab samples were placed in molecular-grade water for $30 \mathrm{~min}$ to allow for removal of residual ethanol. Total genomic DNA was extracted from all samples using a Qiagen DNeasy Tissue Kit following the manufacturer's protocol. Samples were homogenized in ATL buffer and then subject to overnight digestion. DNA was eluted in $100 \mu \mathrm{l}$ AE buffer, quantified using a NanoDrop 2000 (Thermo Scientific), and stored at $-20^{\circ} \mathrm{C}$ prior to use in PCR assays. All extractions were completed within the same $2 \mathrm{~d}$ period and included a blank column extraction that was subjected to PCR analysis and served as a control for extraction contamination.

A random subset (approximately 25\%) of all samples were assessed for the presence of amplifiable high molecular weight, genomic DNA using primers nSSU A (5'AAC CTG GRT TGA TCC TGA TCC TGC CAG T-3') and nSSU B (5'-GAT CCT TCC GCA GGT TCA CCT AC-3') (modified from Medlin et al. 1988), which target the small subunit (SSU) rRNA gene of both the parasite and the crab host. Cycling conditions and reaction concentrations were as described by Pagenkopp Lohan et al. (2012). Five microliters of the resulting PCR product were electrophoresed on a $1.5 \% \mathrm{w} / \mathrm{v}$ agarose gel and visualized under UV light after ethidium bromide staining. The expected fragment size was $\sim 1700 \mathrm{bp}$. All extracted DNA samples from crabs and megalopae were screened for the presence of $H$. perezi DNA using primers previously designed to target the parasite's internal transcribed spacer 1 (ITS1) rRNA region (Small et al. 2007). Briefly, each $20 \mu \mathrm{l}$ reaction contained $10 \mathrm{mM}$ Tris- $\mathrm{HCl}, \mathrm{pH} 8.3,50 \mathrm{mM}$ $\mathrm{KCl}$, $1.5 \mathrm{mM} \mathrm{MgCl}_{2}$, each $\mathrm{dNTP}$ at $0.1 \mathrm{mM}$, each primer at $0.5 \mu \mathrm{M}, 0.5$ units of Taq polymerase (Invitrogen), and $1 \mu$ genomic DNA. Amplifications were performed at an initial denaturation temperature of $94^{\circ} \mathrm{C}$ for $5 \mathrm{~min}$, followed by 35 cycles at $94^{\circ} \mathrm{C}$ for $30 \mathrm{~s}, 58^{\circ} \mathrm{C}$ for $30 \mathrm{~s}$, and $72^{\circ} \mathrm{C}$ for $90 \mathrm{~s}$, with a final 
elongation step at $72^{\circ} \mathrm{C}$ for $5 \mathrm{~min}$. Included in all PCR runs were a negative control that consisted of no DNA, a blank column extraction control, and a positive control consisting of a previous blue crab DNA sample from the field that had routinely amplified in the past. Ten microliters of the resulting PCR product were electrophoresed and visualized as above. The expected fragment was $302 \mathrm{bp}$. Diagnostic PCRs were repeated for all samples that tested positive to confirm diagnoses.

\subsection{Microscopic assessment}

Juvenile crabs collected in 2014-2017 were screened for the presence of $H$. perezi by light microscopy. Briefly, 2 drops of neutral red solution $(0.3 \% \mathrm{w} / \mathrm{v}$ in physiological saline) were added to the wet dissection smear, a cover slip applied, and the sample then immediately assessed by transmitted light microscopy $(200-400 \times)$ for the presence of life history stages, including filamentous trophonts, ameboid trophonts, clump colonies, and prespores. The intensity of infection was categorized as 'light,' 'moderate,' or 'heavy' following methods used by Shields et al. (2017). Light infections were characterized by the presence of filamentous trophonts (vermiform plasmodia) or few ameboid trophonts per microscopic field (1-3 parasites at 200×). Moderate infections typically had 4-10 parasites (filamentous trophonts, ameboid trophonts, and clump colonies) per field at 200x, and heavy infections had $>10$ parasites (ameboid trophonts, prespores) per field.

\section{RESULTS}

\subsection{Prevalence of Hematodinium perezi by diagnostic PCR}

DNA of $H$. perezi was detected in juvenile blue crabs from several locations at various prevalence levels (Table 1). Overall, crabs from Cherrystone and Hungars Creek had relatively low to moderate prevalence levels. DNA of $H$. perezi was not detected in the 293 individual megalopae collected from multiple endemic locations on the Eastern Shore of Virginia between August and October 2010 (Table 2). All DNA samples from megalopae and juvenile crabs collected from 2008, 2009, 2011, and 2012 and assessed for the presence of amplifiable, high molecular weight genomic DNA produced intense banding of the SSU rRNA gene PCR products at $\sim 1700 \mathrm{bp}$. These data, to-
Table 1. Sampling location (abbreviations as in Fig. 1), number sampled (n), size range, and prevalence of Hematodinium perezi as determined by PCR and microscopy in juvenile blue crabs collected between 2008 and 2017 from 6 locations in Virginia, USA. CW: carapace width; nd: not done

\begin{tabular}{|lccccc|}
\hline $\begin{array}{l}\text { Date } \\
(\mathrm{mo} / \mathrm{d} / \mathrm{yr})\end{array}$ & $\begin{array}{c}\text { Sampling } \\
\text { location }\end{array}$ & $\mathrm{n}$ & $\begin{array}{c}\text { CW range } \\
(\mathrm{mm})\end{array}$ & $\begin{array}{c}\text { Prevalence }(\%) \\
\text { PCR }\end{array}$ & Smear \\
\hline $10 / 24 / 2008$ & HC & 58 & $2-14$ & 8.6 & nd \\
$10 / 25 / 2008$ & $\mathrm{CC}$ & 31 & $2-11$ & 54.8 & nd \\
$11 / 04 / 2009$ & HC & 23 & $3-20$ & 4.3 & nd \\
$11 / 04 / 2009$ & CC & 4 & $7-12$ & 75.0 & nd \\
$11 / 22 / 2011$ & CC & 72 & $3-13$ & 5.6 & nd \\
$10 / 22 / 2012$ & CC & 50 & $3-21$ & 18.0 & nd \\
$10 / 22 / 2012$ & SB & 50 & $4-16$ & 78.0 & nd \\
$10 / 02 / 2014$ & SB & 30 & $5-16$ & nd & 100.0 \\
$11 / 05 / 2014$ & SB & 34 & $7-25$ & nd & 97.1 \\
$08 / 26 / 2015$ & SB & 15 & $5-10$ & nd & 66.7 \\
$09 / 22 / 2015$ & SB & 15 & $7-33$ & nd & 80.0 \\
$10 / 07 / 2015$ & SB & 10 & $9-24$ & nd & 100.0 \\
$11 / 09 / 2015$ & CB & 25 & $10-16$ & nd & 100.0 \\
$04 / 21 / 2016$ & CB & 25 & $8-23$ & nd & 60.0 \\
$05 / 16 / 2016$ & CB & 42 & $14-36$ & nd & 59.5 \\
$06 / 20 / 2016$ & CB & 12 & $26-58$ & nd & 91.7 \\
$09 / 25 / 2016$ & CC & 77 & $5-35$ & nd & 1.3 \\
$09 / 26 / 2016$ & HC & 80 & $3-30$ & nd & 5.0 \\
$09 / 27 / 2016$ & CB & 83 & $4-36$ & nd & 50.6 \\
$09 / 28 / 2016$ & PC & 95 & $8-32$ & nd & 0 \\
$09 / 28 / 2016$ & GI & 30 & $11-25$ & nd & 0 \\
$10 / 13 / 2016$ & CB & 80 & $6-46$ & nd & 66.3 \\
$01 / 26 / 2017$ & CB & 30 & $12-25$ & nd & 63.3 \\
$02 / 08 / 2017$ & CB & 37 & $9-42$ & nd & 56.7 \\
\hline
\end{tabular}

Table 2. Sampling location (abbreviations as in Fig. 1) and numbers of blue crab megalopae examined (n) for Hematodinium perezi by PCR. Infection prevalence was $0 \%$ for all sampled populations

\begin{tabular}{|lccc|}
\hline Month & $\begin{array}{c}\text { Sampling } \\
\text { location }\end{array}$ & $\mathrm{n}$ & $\begin{array}{c}\text { Prevalence } \\
(\%)\end{array}$ \\
\hline August & OY & 18 & 0 \\
& SB & 4 & 0 \\
& WA & 62 & 0 \\
& WI & 64 & 0 \\
September & FI & 9 & 0 \\
& CH & 21 & 0 \\
& OY & 7 & 0 \\
& SB & 1 & 0 \\
October & WA & 19 & 0 \\
& WI & 35 & 0 \\
& FI & 2 & 0 \\
& WA & 1 & 0 \\
& WI & 48 & 0 \\
& CH & 3 & 0 \\
\hline \multirow{5}{*}{. } & & & \\
\hline
\end{tabular}

gether with the assessment of individual DNA sample concentrations by NanoDrop quantification (approximately 20-100 $\mathrm{ng}^{-1}$ ), confirmed that amplifiable DNA was present in all assayed samples. 


\subsection{Prevalence of $H$. perezi by light microscopy}

The prevalence of $H$. perezi in juvenile blue crabs from South Bay and Cobb Bay ranged from moderate $(50.6 \%)$ to high $(100.0 \%)$ in all months and years examined (October 2014 to February 2017; Table 1). In South Bay, crabs sampled in late fall months (October/November) had the highest prevalence levels, indicative of recent parasite transmission. In November 2015, a significant eelgrass die-back occurred within South Bay, and few crabs were captured. All subsequent crab collections in this region were carried out in nearby Cobb Bay (Fig. 1). Prevalence levels in Cobb Bay in November $2015(100 \%)$ were comparable to what was observed previously in South Bay and continued to be moderate/high in subsequent samplings at this location, even in the winter months of January and February 2017.

In fall 2016, prevalence levels of $H$. perezi infections in crabs were $5.0 \%$ for Hungers Creek and $1.3 \%$ for Cherrystone Creek. No infections were encountered in samples from Pungoteague Creek or Gwynn's Island on the western shore of Chesapeake Bay (Table 1). Due to small sample sizes in monthly crab collections from South Bay and Cobb Bay, the data on size classes of infected crabs were pooled by season (fall 2015: September-November; spring 2016: April and May; fall 2016: September and October; winter 2017: January and February) for comparison among seasons and host sizes (CW). In fall 2015, $91.5 \%$ of $H$. perezi infections were found in small juvenile crabs (1-20 mm CW, Fig. 2). In comparison, $100 \%$ of infections were observed in larger crabs (11-30 mm CW) sampled in spring 2016. A similar pattern was observed in juveniles collected in fall 2016, where $89.2 \%$ of infections were in smaller crabs (1-20 mm CW) compared to $92.7 \%$ of infections in larger juveniles (11-30 $\mathrm{mm} \mathrm{CW}$ ) from the winter 2017 sample.

\subsection{Infection intensity and life history stages of $H$. perezi}

Light, moderate, and heavy infections were observed in almost all monthly juvenile crab collections from South Bay and Cobb Bay in 2014-2017 (Fig. 3). Although progression of infections may be rapid and ephemeral, light infections were abundant in April, June, August, and September, whereas heavy infections were abundant in October and November. Infection intensity and parasite life

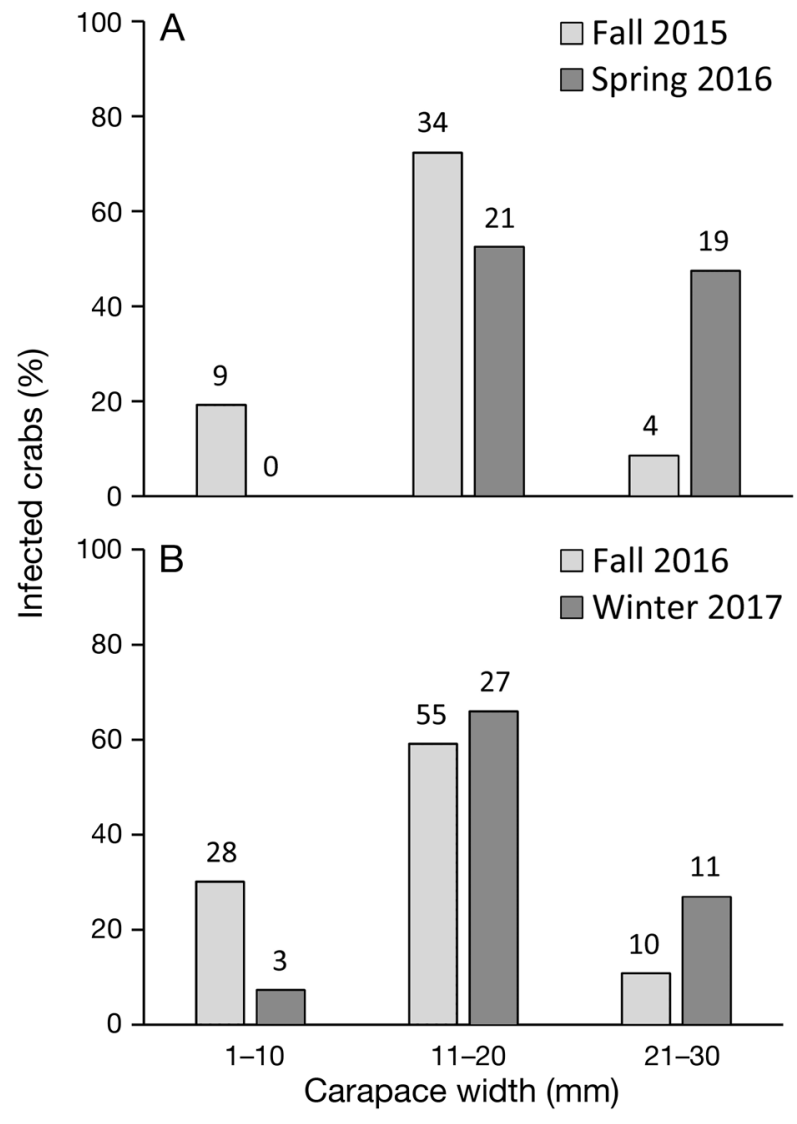

Fig. 2. Comparison of Hematodinium perezi infections in juvenile blue crabs of different size ranges (1-10, 11-20, and 21-30 mm carapace width). (A) Crabs collected in fall 2015 (September-November) and spring 2016 (April, May). (B) Crabs collected in fall 2016 (October, November) and winter 2017 (January, February). Sample size is shown above each bar

stage were highly variable and changed considerably among months, indicating rapid development, growth, and differentiation. Ameboid trophonts were the most common stage observed (Fig. 4). Filamentous trophonts, the earliest diagnostic stage in blue crabs, were observed in August and September 2015, and also in April, June, September, and October 2016 (Fig. 4). Of particular note, filamentous trophonts were observed in $93.4 \%$ of infected crabs in April 2016. In subsequent monthly samplings, ameboid trophonts and clump colony stages were common. Prespore stages, which are indicative of imminent sporulation and release from an infected crab, were observed in October 2014 and 2015 (16.7 and 10.0\%, respectively) and in May, September, and October 2016 (4.2, 26.2, and 5.7\%, respectively). Light, moderate, and heavy ameboid trophont infections were observed in crabs sampled in January and February 2017. 


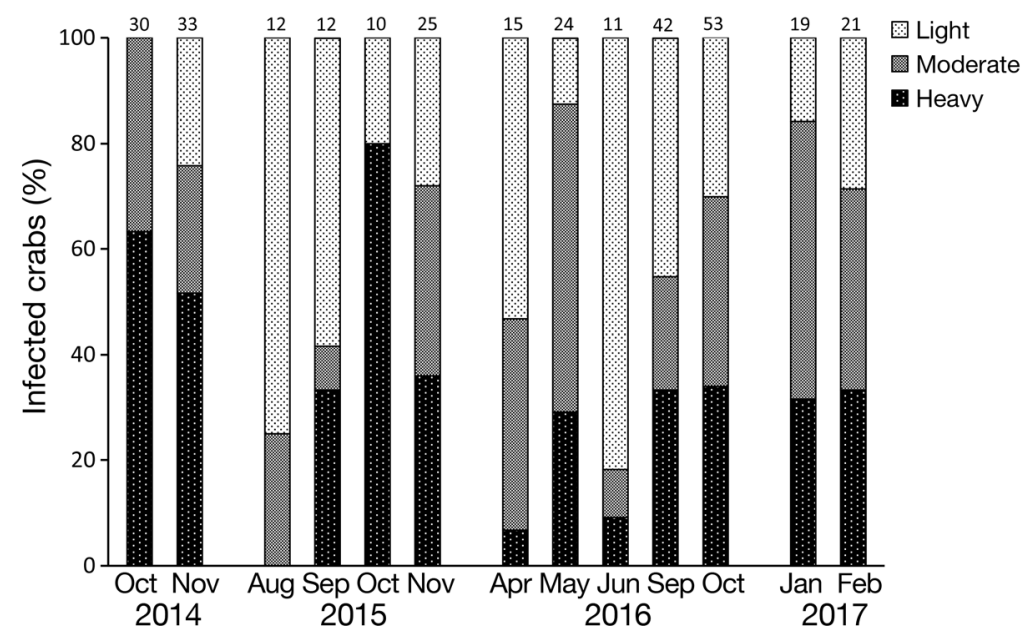

Fig. 3. Hematodinium perezi intensity of infection in juvenile blue crabs sampled from South Bay (October 2014-October 2015) and Cobb Bay (November 2015-February 2017). Sample size is shown above each bar

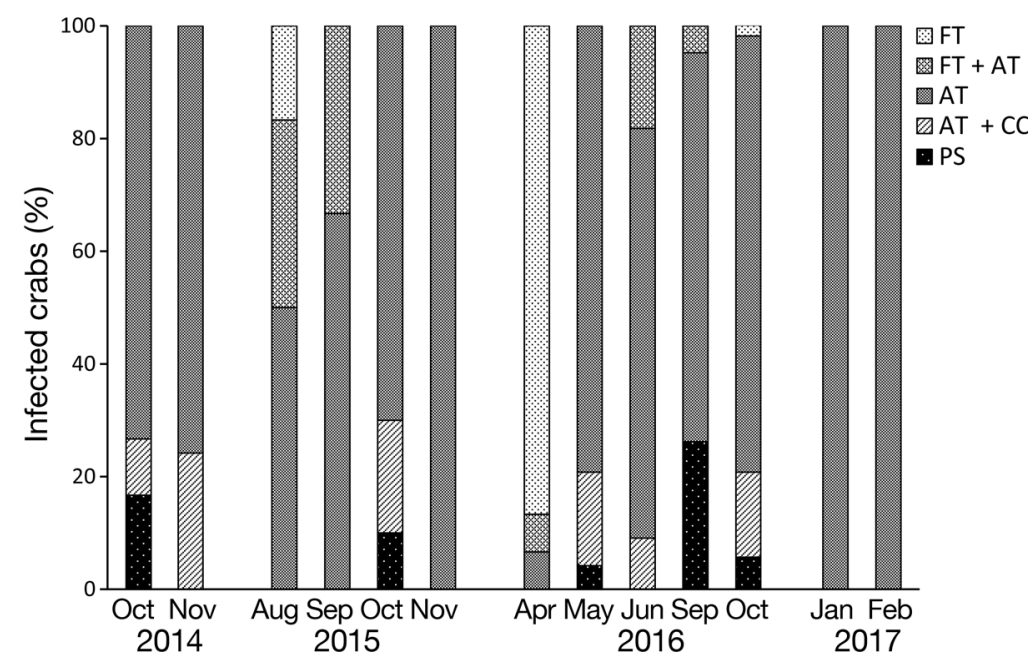

Fig. 4. Life history stages of Hematodinium perezi in early juvenile blue crabs sampled from South Bay (October 2014-October 2015) and Cobb Bay (November 2015-February 2017). FT: filamentous trophont; AT: ameboid trophont; CC: clump colony; PS: prespore. Sample sizes are given in Fig. 3

\section{DISCUSSION}

Hematodinium perezi is endemic in early benthic juvenile blue crabs from the high-salinity, oceanic coastal bays along the southern tip of the Delmarva Peninsula. Prevalence levels ranged from 50.6 to $100 \%$. Infections were found in all size classes examined, the smallest of which were $\sim 2 \mathrm{~mm} \mathrm{CW}$, and in all months sampled. The prespore stage, which is indicative of imminent sporulation, was observed in spring (May) and fall (September and October). $H$. perezi DNA was not detected in megalopae transit- ing through the high-salinity bays, despite doing so during peak periods in parasite infection of early benthic juveniles. Taken together, these data suggest that $H$. perezi rapidly infects early benthic instars of blue crabs in early summer and fall as they recruit into structured habitats (e.g. eelgrass, oyster beds) in these high-salinity embayments. Our data also show that the parasite can overwinter at moderate to high prevalence levels in early benthic juveniles. Given its high mortality rate in both adults and juveniles (Messick \& Shields 2000, Shields \& Squyars 2000), its high mortality rate associated with warm water temperatures $\left(25^{\circ} \mathrm{C}\right.$ and above; HuchinMian et al. 2018), and high prevalence levels in early instars, $H$. perezi appears to significantly affect recruitment of early juvenile crabs in the high-salinity bays along the Delmarva Peninsula.

As with many pathogens, there is considerable temporal variability in the prevalence of $H$. perezi in the high-salinity bays of the Delmarva Peninsula. These embayments have salinities of 230-34 psu and are mostly shallow expanses with moderate to high water residence times that serve to amplify transmission of the parasite (Shields 2012). For example, Cobb Bay has a residence time of $\sim 7 \mathrm{~d}$ (Herman et al. 2007), a feature that when coupled with the viability of $H$. perezi dinospores at high salinity, likely enhances transmission of the parasite. Transmission occurs rapidly in early fall months in endemic locations, and water temperature appears to be an important driver modulating transmission (Huchin-Mian et al. 2017, Shields et al. 2017). Furthermore, a recent laboratory study with naturally infected early instars indicated that water temperatures around $25^{\circ} \mathrm{C}$ are optimal for parasite development and sporulation (Huchin-Mian et al. 2018). Infected crabs held at lower temperatures did not sporulate and maintained infections over extended periods (90 d).

We did not find evidence of $H$. perezi infections in megalopae entering into the coastal bays. This finding validated earlier histological examinations which were also negative (J. D. Shields unpubl. data). This is in contrast with recent studies from Louisiana, in 
which $H$. perezi DNA was detected in blue crab megalopae (Sullivan et al. 2016, Sullivan \& Neigel 2017). Although there are ecosystem differences between the Delmarva Peninsula and the Gulf of Mexico, there is a potential confounding factor in the study by Sullivan et al. (2016) and their later analyses. The PCR primers used by Sullivan et al. (2016) were originally designed to target the conserved $18 \mathrm{~S}$ rRNA gene of a different Hematodinium sp., one that infects Tanner crabs Chionoecetes bairdi and snow crabs C. opilio from the North Pacific (Friedman et al. 2009). Due to the conserved nature of the SSU rRNA gene, these same primers would detect $H$. perezi; however, molecular assays used to detect dinoflagellates based on this conserved gene have significantly reduced specificity (Litaker et al. 2007, Small et al. 2007). Hanif et al. (2013) succinctly demonstrated this when testing a previously published assay targeting the $H$. perezi SSU gene (Nagle et al. 2009) as they amplified at least 10 protozoan species that were identical in sequence at the primer binding sites, none of which were Hematodinium species. The list of organisms with perfect matches to the primer sequences included several species found in midAtlantic and Gulf coast waters (Hanif et al. 2013). We therefore recommend that in future studies where parasite DNA is detected in larval stages or microcrustaceans, the amplicons are sequenced or there is definitive proof of infection through in situ hybridization techniques. In addition, studies of larval host stages infected with $H$. perezi or pathogens should be careful to rule out external contamination of the cuticle or gills (Burreson 2008, Shields 2017).

We observed $H$. perezi overwintering in early benthic crabs from the high-salinity bays during winter. Infections were observed at all intensities and at moderate prevalence levels (55-60\%). We have previously reported $H$. perezi infections in large juvenile and adult blue crabs from winter dredge surveys in the winter months of January, February, and March from nearby Wachapreague Creek (Shields et al. 2015). In that study, active infections were observed in all months, and they rapidly developed into highintensity infections when held at $15^{\circ} \mathrm{C}$. It is therefore likely that early benthic juveniles respond in a similar manner, and thus likely explains the bimodal peaks in prevalence observed in larger juveniles and adults, and the detection of $H$. perezi in environmental samples (Pitula et al. 2012, Hanif et al. 2013, Lycett \& Pitula 2017).

Lastly, we observed infections in small juveniles in early fall months, and in larger crabs in subsequent months (e.g. winter or the following spring). At tem- perate latitudes (e.g. Chesapeake Bay) megalopae settlement generally occurs from August to November. Assuming that movement of juveniles is minimal among adjacent estuaries and sub-estuaries (van Montfrans et al. 1991), our data suggest that juvenile crabs surviving infections with $H$. perezi in late fall can molt, grow, and carry infections forward into spring of the following year. Our field observations are consistent with recent laboratory studies which showed that Hematodinium-infected juvenile crabs were capable of molting at frequencies similar to those of uninfected crabs (Huchin-Mian et al. 2018). Huchin-Mian et al. (2018) also showed that infected juvenile blue crabs held at mild temperatures $(10,15$, and $20^{\circ} \mathrm{C}$ ) have high survival, but their survival is diminished at low temperature $\left(4^{\circ} \mathrm{C}\right)$. Therefore, water temperature during winter months may significantly modulate the survival of parasite and infected host, and ultimately influence the transmission dynamics in the following spring/summer. Further studies over winter and spring months are needed to investigate this hypothesis.

Acknowledgements. We thank Gina Ralph, Rom Lipcius, Mike Seebo, Edward Smith, Sean Fate, Pattie O'Leary, Dana Kinney, Brittnee Barris, Tom Dolan, Shelley Katsuki, and Kersten Wheeler for help with collection of juvenile crabs. We also thank Professor Ryan Carnegie for reviewing an earlier version of this manuscript. This work was funded by a Virginia Sea Grant Project Development grant R/722128PD, National Science Foundation Ecology of Infectious Diseases (EID) Program grant OCE BE-UF0723662, and a Saltonstall-Kennedy Program grant NA15NMF4270300. This is contribution number 3813 from the Virginia Institute of Marine Science.

\section{LITERATURE CITED}

Burreson EM (2008) Misuse of PCR assay for diagnosis of mollusc protistan infections. Dis Aquat Org 80:81-83

Friedman CS, Crosson LM, Hauser L, Morado JF (2009) Development and application of a quantitative real-time polymerase chain reaction (qPCR) assay to assess the life history of Hematodinium, a parasitic dinoflagellate, and its impact on Tanner crab populations in Alaska. North Pacific Research Board Project 623, Final Report

Hanif AW, Dyson WD, Bowers HA, Pitula JS, Messick GA, Jagus R, Schott EJ (2013) Variation in spatial and temporal incidence of the crustacean pathogen Hematodinium perezi in environmental samples from Atlantic Coastal Bays. Aquat Biosyst 9:11

*Herman J, Shen J, Huang J (2007) Tidal flushing characteristics in Virginia's tidal embayments. Virginia Coastal Zone Management Program, Richmond, VA

*Huchin-Mian JP, Small HJ, Shields JD (2017) Patterns in the natural transmission of the parasitic dinoflagellate $\mathrm{He}$ matodinium perezi in American blue crabs, Callinectes sapidus from a highly endemic area. Mar Biol 164:153 
Huchin-Mian JP, Small HJ, Shields JD (2018) The influence of temperature and salinity on mortality of recently recruited blue crabs, Callinectes sapidus, naturally infected with Hematodinium perezi (Dinoflagellata). J Invertebr Pathol 152:8-16

Johnson PT (1986) Parasites of benthic amphipods: dinoflagellates (Duboscquodinida: Syndinidae). Fish Bull 84: 605-614

Lee RF, Frischer ME (2004) The decline of the blue crab. Am Sci 92:548-553

Litaker RW, Vandersea MW, Kibler SR, Reece KS and others (2007) Recognizing dinoflagellate species using ITS rDNA sequences. J Phycol 43:344-355

Kycett KA, Pitula JS (2017) Disease ecology of Hematodinium perezi in a high salinity estuary: investigating seasonal trends in environmental detection. Dis Aquat Org 124:169-179

Medlin L, Elwood HJ, Stickel S, Sogin ML (1988) The characterization of enzymatically amplified eukaryotic 16Slike rRNA-coding regions. Gene 71:491-499

Messick GA (1994) Hematodinium perezi infections in adult and juvenile blue crabs Callinectes sapidus from coastal bays of Maryland and Virginia, USA. Dis Aquat Org 19: 77-82

Messick GA, Shields JD (2000) Epizootiology of the parasitic dinoflagellate Hematodinium sp. in the American blue crab Callinectes sapidus. Dis Aquat Org 43:139-152

Messick GA, Sindermann CJ (1992) Synopsis of principal diseases of the blue crab, Callinectes sapidus. Tech Memo NMFS-F/NEC-88. NOAA NMFS, Washington, DC

Nagle L, Place AR, Schott EJ, Jagus R, Messick G, Pitula JS (2009) Real-time PCR-based assay for quantitative detection of Hematodinium sp. in the blue crab Callinectes sapidus. Dis Aquat Org 84:79-87

Newman MW, Johnson CA (1975) A disease of blue crabs (Callinectes sapidus) caused by a parasitic dinoflagellate, Hematodinium sp. J Parasitol 61:554-557

Pagenkopp Lohan KM, Reece KS, Miller TL, Wheeler KN, Small HJ, Shields JD (2012) The role of alternate hosts in the ecology and life history of Hematodinium sp., a parasitic dinoflagellate of the blue crab (Callinectes sapidus). J Parasitol 98:73-84

Pagenkopp Lohan KM, Small HJ, Shields JD, Place AR, Reece KS (2013) Conservation in the first internal transcribed spacer (ITS1) region of Hematodinium perezi (genotype III) from Callinectes sapidus. Dis Aquat Org 103:65-75

Pitula JS, Dyson WD, Bahkt HB, Njoku I, Chen F (2012) Temporal distribution of genetically homogeneous 'freeliving' Hematodinium sp. in a Delmarva coastal ecosystem. Aquat Biosyst 8:16

Editorial responsibility: Stephen Feist, Weymouth, UK
Ralph GM, Seitz RD, Orth RJ, Knick KE, Lipcius RN (2013) Broad-scale association between seagrass cover and juvenile blue crab density in Chesapeake Bay. Mar Ecol Prog Ser 488:51-63

Sheppard M, Walker A, Frischer ME, Lee RF (2003) Histopathology and prevalence of the parasitic dinoflagellate Hematodinium sp. in crabs (Callinectes sapidus, Callinectes similis, Neopanope sayi, Libinia emarginata, Menippe mercenaria) from a Georgia estuary. J Shellfish Res 22:873-880

Shields JD (2012) The impact of pathogens on exploited populations of decapod crustaceans. J Invertebr Pathol 110:211-224

Shields JD (2017) Collection techniques for the analyses of pathogens in crustaceans. J Crustac Biol 37:753-763

Shields JD, Overstreet RM (2007) Parasites, symbionts, and diseases. In: Kennedy V, Cronin LE (eds) The blue crab Callinectes sapidus. University of Maryland Sea Grant College, College Park, MD, p 299-417

Shields JD, Squyars CM (2000) Mortality and hematology of blue crabs, Callinectes sapidus, experimentally infected with the parasitic dinoflagellate Hematodinium perezi. Fish Bull 98:139-152

Shields JD, Sullivan SE, Small HJ (2015) Overwintering of the parasitic dinoflagellate Hematodinium perezi in dredged blue crabs (Callinectes sapidus) from Wachapreague Creek, Virginia. J Invertebr Pathol 130: 124-132

Shields JD, Huchin-Mian JP, O'Leary PA, Small HJ (2017) New insight into the transmission dynamics of the crustacean pathogen Hematodinium perezi (Dinoflagellata) using a novel sentinel methodology. Mar Ecol Prog Ser 573:73-84

* Small HJ, Shields JD, Hudson KL, Reece KS (2007) Molecular detection of the Hematodinium sp. infecting the blue crab, Callinectes sapidus. J Shellfish Res 26: 131-139

Sullivan TJ, Neigel JE (2017) Differential host mortality explains the effect of high temperature on the prevalence of a marine pathogen. PLOS ONE 12:e0187128

* Sullivan TJ, Gelpi CG, Neigel JE (2016) Molecular detection of the parasitic dinoflagellate Hematodinium perezi from blue crabs Callinectes sapidus in Louisiana, USA. Dis Aquat Org 120:83-88

*van Montfrans J, Ryer CH, Orth RJ (1991) Population dynamics of blue crabs Callinectes sapidus Rathbun in a lower Chesapeake Bay tidal marsh creek. J Exp Mar Biol Ecol 153:1-14

Williams AB (1984) Shrimps, lobsters, and crabs of the Atlantic coast of the Eastern United States, Maine to Florida. Smithsonian Institution Press, Washington, DC

Submitted: January 31, 2019; Accepted: March 12, 2019 Proofs received from author(s): May 20, 2019 